\title{
Eradication of Helicobacter Pylori in Iran: A Review
}

\author{
Hafez Fakheri ${ }^{1}$, Mehdi Saberi Firoozi ${ }^{2}$, Zohreh Bari ${ }^{3, *}$
}

\section{ABSTRACT}

1. Professor of Gastroenterology, Gut and Liver Research Center, Mazandaran University of Medical Sciences, Sari, Iran

2. Professor of Gastroenterology, Digestive Disease Research Institute, Tehran University of Medical Sciences, Tehran, Iran

3. Assistant professor of Gastroenterology, Gut and Liver Research Center, Mazandaran University of Medical Sciences, Sari, Iran

* Corresponding Author: Zohreh Bari, MD

Gut and Liver Research Center, Mazandaran University of Medical Sciences, 48166 33131, Sari, Iran

Tel: +981133350670

fax: + 981133363754

Email: zohreb252@yahoo.com

Received: 05 Sep. 2017

Accepted: 02 Dec. 2017
Helicobacter pylori (H. pylori) infection is one of the most common bacterial infections, affecting almost half of the world's population. It is associated with peptic ulcer disease, gastric adenocarcinoma, and lymphoma. In Iran, the prevalence of $H$. pylori infection has been reported to be between $36 \%$ and $90 \%$ in different geographic regions.

Several studies have assessed the efficacy of different therapeutic options for firstline and second-line H. pylori eradication in Iran; however, the results are conflicting. Therefore, we conducted a review to evaluate different studies in order to select the best options and to provide recommendations for H. pylori eradication in Iran. Accordingly, we searched through PubMed to obtain relevant randomized clinical trials published in English language up to June 2017.

According to our study, among first-line eradication regimens, bismuth-based furazolidone- or clarithromycin-containing quadruple therapies, hybrid regimen, and concomitant therapy seem to be appropriate options. Also, 10- or 14-day clarithromycin-containing triple therapy can be used if local $H$. pylori resistance to clarithromycin is known to be less than $15 \%$.

For second-line H. pylori eradication, bismuth-based quadruple therapies and 14-day levofloxacin-based triple therapy can be used, provided that antibiotics other than those used in the first-line regimen are used. Third-line H. pylori eradication regimens have not been addressed in Iranian studies. However, most guidelines recommend treatment according to the results of culture and susceptibility testing.

Although we limited our investigation to $H$. pylori eradication regimens in Iran, the results are transferrable to any region as long as the patterns of antibiotic resistance are the same.

\section{KEYWORDS:}

Helicobacter pylori, Eradication, Iran

Please cite this paper as:

Fakheri H, Saberi Firoozi M, Bari Z. Eradication of Helicobacter Pylori in Iran: A Review. Middle East J Dig Dis 2018;10:5-17. doi: 10.15171/mejdd.2017.84.

\section{INTRODUCTION}

Helicobacter pylori (H. pylori) infection is among the most common bacterial infections, affecting almost half of the world's population. ${ }^{1}$ It is associated with peptic ulcer disease, gastric adenocarcinoma, and lymphoma.

In Iran, the prevalence of $H$. pylori infection has been reported to be at least $36 \%$ in Kurdistan and as high as $90 \%$ in Ardabil. ${ }^{2,3}$ Therefore, it is essential to introduce an effective $H$. pylori eradication regimen in this country. On the other hand, although $H$. pylori infection is very prevalent in Iran, it is not cost-effective to treat every person infected by the bacterium. According to Maastricht V Consensus Report, the indications for $H$. pylori eradication include: peptic ulcer disease (regardless of activeness and complications), mucous-associated lymphoid 
Table 1: Resistance pattern of $\boldsymbol{H}$. pylori to different antibiotics during the previous years in different parts of Iran

\begin{tabular}{|c|c|c|c|c|c|c|c|c|c|}
\hline City & Year & Number & Method & Amox. & Met. & Tetra. & Cla. & Other & MDR \\
\hline Tehran $^{5}$ & $1997-2000$ & 70 & DDM & 1.4 & 33 & 0 & 1.4 & & \\
\hline Hamadan $^{6}$ & $2001-4$ & 135 & DDM & 3.7 & 36.3 & 0.7 & 3.7 & & \\
\hline Tehran $^{7}$ & 2005 & 120 & DDM & 1.6 & 57.5 & 0 & 16.7 & & \\
\hline Tehran $^{8}$ & $2005-08$ & 160 & DDM & 7.3 & 55.6 & 38.1 & 7.3 & Fur: 4.5 & \\
\hline Mashhad $^{9}$ & 2008 & 124 & DDM & 9.8 & 64.6 & 0 & 17.1 & & \\
\hline Tehran $^{10}$ & 2010 & 42 & DDM & 2.4 & 40.5 & 4.8 & 14.3 & Cip: 2.4 & \\
\hline $\operatorname{Sari}^{11}$ & 2011 & 197 & DDM & 23.9 & 65.5 & 37 & 45 & Fur: 61 & $\begin{array}{c}\text { Dual Met }+ \\
\text { Cla: } 22.6\end{array}$ \\
\hline $\operatorname{Sari}^{12}$ & 2012 & & DDM & 10 & 78 & 9.3 & 34 & $\begin{array}{l}\text { Levo: } 5.3 \\
\text { Moxi: } 4.6\end{array}$ & \\
\hline Tabriz $^{13}$ & 2012 & 112 & DDM & 28 & 76.8 & 18.6 & 14.3 & $\begin{array}{c}\text { Cip: } 33 \\
\text { Rif: } 28.6\end{array}$ & \\
\hline Tehran $^{14}$ & 2013 & 153 & - & 7.2 & 63.8 & - & 26.5 & & \\
\hline Ilam $^{15}$ & 2013 & 50 & DDM & 6 & 44 & 6 & 16 & Azith: 4 & \\
\hline North of Iran ${ }^{16}$ & 2015 & 20 & DDM & 5 & 57 & 27 & 24 & $\begin{array}{c}\text { Fur: } 38 \\
\text { Azith: } 19\end{array}$ & \\
\hline Kashan $^{17}$ & 2015 & 95 & E test & & & & 33.7 & & \\
\hline Isfahan $^{18}$ & 2013 & 78 & $\mathrm{DDM} / \mathrm{E}$ & 6 & 55 & & 15 & & \\
\hline Mashhad $^{9}$ & 2013 & 124 & DDM & 9.8 & 64 & 0 & 17 & & \\
\hline Tehran $^{19}$ & 2015 & 111 & - & 15 & 51 & & 32 & $\begin{array}{l}\text { Cip: } 30 \\
\text { Rif: } 14\end{array}$ & $\begin{array}{c}\text { Dual Met + } \\
\text { Cla: } 22.6\end{array}$ \\
\hline Systematic review ${ }^{20}$ & 2015 & $\begin{array}{c}21 \\
\text { Studies }\end{array}$ & - & 16 & 61 & 12 & 22 & $\begin{array}{l}\text { Cip: } 21 \\
\text { Levo: } 5 \\
\text { Fur: } 21\end{array}$ & \\
\hline Shiraz $^{21}$ & 2016 & 100 & E test & & & & 20 & & \\
\hline $\operatorname{Sari}^{22}$ & 2016 & 30 & DDM & 10 & 63.3 & 6.6 & 16.6 & Levo: 3.3 & \\
\hline
\end{tabular}

tissue lymphoma (MALT), long term non-steroidal anti-inflammatory drug (NSAID) therapy in patients with a history of peptic ulcer disease (PUD), patients receiving long term proton pump inhibitors (PPIs), unexplained iron deficiency anemia, idiopathic thrombocytopenic purpura, gastric cancer prevention in special situations (including first degree relatives or previous history of gastric neoplasia), gastric atrophy, chronic gastritis with dyspepsia, chronic gastritis with mucosal atrophy/erosions, and if requested by individual patient. ${ }^{4}$

In order to treat $H$. pylori infection, antibiotic resistance is the most important issue. During the previous 20 years, resistance of $H$. pylori to antibiotics has increased in different parts of Iran (table 1). This is mainly due to common use of antibiotics in this country. Therefore, the most ideal option is to treat according to the results of culture and susceptibility tests. However, culture is not easily available.

In this article we have reviewed the efficacy of different first-line and second-line H. pylori eradication therapies in Iran.

\section{Data Collection Method:}

The present narrative review includes randomized controlled trials related to $H$. pylori eradication in Iran. In order to find the relevant papers, we searched through PubMed website for studies published in English language up to June 2017 with the following key words: ("Helicobacter pylori" or "H. pylori"), and (Iran), and ("eradication" or "therapy" or "treatment"). Two gastroenterologists selected relevant studies after reviewing their abstracts. Since the number of secondline H. pylori eradication regimens were very few, non-randomized clinical trials were also included for the assessments of second-line therapies. 
Table 2: The efficacy of standard triple therapy with different durations of administration

\begin{tabular}{|c|c|c|c|c|c|c|c|c|}
\hline Year & City & Therapy & $\begin{array}{c}\text { Treatment } \\
\text { duration } \\
\text { (days) }\end{array}$ & $\begin{array}{l}\text { Number of } \\
\text { patients. }\end{array}$ & $\begin{array}{l}\text { Underlying } \\
\text { disease }\end{array}$ & $\begin{array}{c}\text { Eradication } \\
\text { assessment } \\
\text { method. }\end{array}$ & $\begin{array}{c}\text { Duration } \\
\text { from therapy } \\
\text { (week) }\end{array}$ & $\begin{array}{c}\text { Per-protocol } \\
\text { eradication rate }\end{array}$ \\
\hline 2003 & Ardabi $^{24}$ & $\mathrm{OAC}$ & 7 & 45 & Gastritis & UBT & 8 & 42 \\
\hline 2006 & Tehran $^{25}$ & $\mathrm{OAC}$ & 7 & 120 & H. pylori $(+)$ & UBT & 6 & 91.8 \\
\hline 2012 & Kerman $^{26}$ & OPC & 7 & 34 & H. pylori $(+)$ & $?$ & $?$ & 73 \\
\hline 2010 & $\operatorname{Rasht}^{27}$ & $\mathrm{OAC}$ & 10 & 107 & NUD & $\begin{array}{c}\text { Stool } \\
\text { Antigen }\end{array}$ & 8 & 90.7 \\
\hline 2010 & Tehran $^{28}$ & $\mathrm{OAC}$ & 10 & 104 & PUD & UBT & 8 & 90.4 \\
\hline 2013 & Ghom $^{29}$ & OAC & 10 & 76 & H. pylori $(+)$ & UBT & 6 & 83 \\
\hline 2013 & Ahvaz $^{30}$ & $\begin{array}{l}\text { OAC } \\
\text { LAC } \\
\text { EAC }\end{array}$ & 10 & $\begin{array}{l}98 \\
97 \\
98\end{array}$ & H. pylori $(+)$ & UBT & 6 & $\begin{array}{l}91.9 \\
80.4 \\
91.8\end{array}$ \\
\hline 2015 & Ahvaz ${ }^{31}$ & $\mathrm{OAC}$ & 10 & 100 & H. pylori $(+)$ & UBT & 8 & 93.9 \\
\hline 2007 & Kermashah $^{32}$ & $\begin{array}{c}\text { OAC } \\
\text { (C: half dose) } \\
\text { OAC }\end{array}$ & $\begin{array}{l}14 \\
14\end{array}$ & $\begin{array}{l}53 \\
53\end{array}$ & H. pylori $(+)$ & UBT & 6 & $\begin{array}{l}88 \\
89\end{array}$ \\
\hline 2009 & Yazd $^{35}$ & $\mathrm{OAC}$ & 14 & 53 & H. pylori $(+)$ & UBT & $4-6$ & 70 \\
\hline 2013 & Shiraz $^{34}$ & $\begin{array}{l}\text { OAC } \\
\text { OPC }\end{array}$ & 14 & $\begin{array}{l}110 \\
110\end{array}$ & PUD & UBT & 6 & $\begin{array}{l}90.8 \\
87\end{array}$ \\
\hline 2014 & Tehran $^{33}$ & $\mathrm{OAC}$ & 14 & 39 & GU & Biopsy & 8 & 82.9 \\
\hline 2015 & Tehran $^{36}$ & $\begin{array}{l}\text { OAC } \\
\text { OAC }\end{array}$ & $\begin{array}{c}14 \\
14(\mathrm{~A}: 28)\end{array}$ & $\begin{array}{l}33 \\
33\end{array}$ & H. pylori $(+)$ & $\begin{array}{l}\text { Stool } \\
\text { Antigen }\end{array}$ & 4 & $\begin{array}{l}63.6 \\
90.9\end{array}$ \\
\hline
\end{tabular}

O: Omeprazole, L: Lansoprazole, P: Pantoprazole, E: Esomeprazole, Amox: Amoxicillin, Cla: Clarithromycin, GU: Gastric ulcer, PUD: Peptic ulcer disease, NUD: Non-ulcer dyspepsia, UBT: Urea breath test

Data including the kind of therapy, number of patients, indications for treatment, intention to treat, and per-protocol H. pylori eradication rates were recorded in data gathering forms.

\section{First-line H. pylori Eradication Regimens:}

The ideal first-line H. pylori therapy is the regimen with more than $90 \%$ per-protocol eradication rate. However, according to Toronto Consensus Report, achieving $>85 \%$ eradication rate can also be considered appropriate. ${ }^{23}$

\section{Clarithromycin-Containing Triple Therapy:}

Clarithromycin-containing triple therapy consisted of clarithromycin plus a proton pump inhibitor (PPI), and amoxicillin or metronidazole is considered as the standard triple therapy. According to Maastricht V and Toronto Consensus Reports, standard triple therapy is suitable only in countries with less than $15 \% \mathrm{H}$. pylori resistance to clarithromycin. ${ }^{4,23}$

In Iran, 14 studies have evaluated the efficacy of clarithromycin-containing triple therapy, but the durations of regimens were different. Three studies evaluated 7-day therapy and only one could achieve ideal eradication rate. ${ }^{24-26}$ Also, five studies assessed 10-day triple therapy. Four of these studies reported $>90 \%$ H. pylori eradication rate. ${ }^{27-31}$ Furthermore, five other studies evaluated the efficacy of 14-day standard therapy, of them three showed appropriate eradication of $\mathrm{H}$. pylori, ${ }^{32-36}$ (table 2).

Accordingly, although $H$. pylori resistance to clarithromycin is increasing in our country, 10-day and 14-day standard triple therapies still seem to be appropriate options for first-line H. pylori eradication in Iran. In fact, the effects of antibiotics in vivo are not the same as those observed in vitro. Furthermore, low gastric $\mathrm{pH}$ may facilitate antibiotic activity. Most antibiotics have the most activity at neutral $\mathrm{pH}$; however, clarithromycin especially has the most activity at higher $\mathrm{pH}$ (around 8). Thus, clarithromycin is the only antibiotic that benefits from a high $\mathrm{pH}$ caused by PPI. ${ }^{37}$ 
H. pylori Eradication in Iran

Table 3: The efficacy of furazolidone-containing triple therapy with different durations of administration

\begin{tabular}{|c|c|c|c|c|c|c|c|c|}
\hline Year & City & Therapy & $\begin{array}{c}\text { Treatment } \\
\text { duration } \\
\text { (days) }\end{array}$ & $\begin{array}{c}\text { Number of } \\
\text { patients. }\end{array}$ & $\begin{array}{l}\text { Underlying } \\
\text { disease }\end{array}$ & $\begin{array}{c}\text { Eradication } \\
\text { assessment } \\
\text { method. }\end{array}$ & $\begin{array}{l}\text { Duration } \\
\text { from therapy } \\
\text { (week) }\end{array}$ & $\begin{array}{c}\text { Per-protocol } \\
\text { eradication rate }\end{array}$ \\
\hline 2003 & Ardabi $^{24}$ & $\begin{array}{c}\text { OFT } \\
\text { OFT } \\
\text { (T: } 200 \text { BID } \\
\text { F: } 500 \text { BID) }\end{array}$ & $\begin{array}{l}4 \\
7\end{array}$ & $\begin{array}{l}41 \\
42\end{array}$ & Gastritis & UBT & 8 & $\begin{array}{l}20.6 \\
29.4\end{array}$ \\
\hline 2014 & $\operatorname{Sari}^{39}$ & $\begin{array}{c}\text { OAF } \\
\text { (F: 200 BID) } \\
\text { OAF } \\
\text { (F: } 200 \text { TDS) }\end{array}$ & $\begin{array}{l}10 \\
10\end{array}$ & $\begin{array}{l}105 \\
105\end{array}$ & PUD & UBT & 8 & $\begin{array}{l}81 \\
89\end{array}$ \\
\hline 2015 & $\mathrm{Ahvaz}^{30}$ & $\begin{array}{c}\text { OCipF } \\
\text { (F: } 100 \text { BID) }\end{array}$ & 10 & 100 & H. pylori $(+)$ & UBT & 8 & 62 \\
\hline 2015 & $\operatorname{Sari}^{38}$ & $\begin{array}{c}\text { OAF } \\
\text { (F: } 200 \text { TDS) }\end{array}$ & 10 & 116 & PUD & UBT & 8 & 90.5 \\
\hline 2003 & Yazd $^{42}$ & $\begin{array}{c}\text { OAF } \\
\text { (F: } 200 \mathrm{BID}) \\
\text { OAF } \\
\text { (F: } 50 \mathrm{BID})\end{array}$ & 14 & $\begin{array}{l}63 \\
61\end{array}$ & DU & Biopsy & 6 & $\begin{array}{l}88.9 \\
67.9\end{array}$ \\
\hline 2004 & $\operatorname{Sari}^{40}$ & $\begin{array}{c}\text { OAF } \\
\text { (F: } 200 \text { BID) }\end{array}$ & 14 & 50 & DU & UBT & 12 & 54 \\
\hline 2011 & Ghom $^{41}$ & $\begin{array}{c}\text { OAF } \\
\text { (F: 200 BID) }\end{array}$ & 14 & 43 & PUD & UBT & 12 & 61 \\
\hline
\end{tabular}

O: Omeprazole, Amox: Amoxicillin, Tetra: Tetracycline, Fur: Furazolidone, DU: Duodenal ulcer, PUD: Peptic ulcer disease, NUD: Non-ulcer dyspepsia, UBT: Urea breath test, BID: twice daily, TDS: three times daily

\section{Furazolidone-Containing Triple Therapy:}

Furazolidone is an alternative to metronidazole in areas with high $H$. pylori resistance to metronidazole. Seven studies have evaluated furazolidonecontaining triple therapies in Iran (including a PPI + amoxicillin + furazolidone). One of the earliest studies had compared the efficacy of 4-day versus 7-day furazolidone-based triple therapy. But both regimens showed very low per-protocol H. pylori eradication rates $\left(20 \%\right.$ vs. $29 \%$, respectively). ${ }^{24}$ During the previous 3 years, three other studies evaluated the efficacy of 10-day furazolidone-based triple therapies. Among these studies, those with higher doses of furazolidone ( $200 \mathrm{mg}$ three times a day vs. $200 \mathrm{mg}$ twice a day or daily) could achieve optimal eradication rates. ${ }^{30,38,39}$

Furthermore, three other studies assessed the efficacy of 14-day furazolidone-based triple therapies, but only one study could achieve appropriate eradication rate. ${ }^{40-42}$ Administration of low doses of furazolidone seems to be the main reason for failure of the mentioned regimens (table 3 ).

Although regimens with higher doses of furazolidone could achieve acceptable eradication rates, adverse reactions to the treatment increased with higher doses of the drug. Therefore, this regimen cannot be suggested as a suitable option.

\section{Bismuth-Metronidazole Quadruple Therapy:}

Up to now, 12 studies have evaluated the efficacy of 10-day and 14-day bismuth plus metronidazolecontaining quadruple therapies in Iran. ${ }^{25,27,28,33,43,49}$ However, only three of these studies could achieve acceptable $H$. pylori eradication rates (table 4).

According to Maastricht V Consensus Report, in countries with low or even high dual resistance to clarithromycin and metronidazole, bismuth-containing quadruple therapies can be used as suitable first-line options. ${ }^{4}$ However, the results of Iranian studies are not concordant with this recommendation. Searching through the mentioned studies shows that administration of sub-optimal doses of bismuth or metronidazole is probably the main reason for failure of this regimen in Iranian studies. On the other hand, H. pylori resistance to metronidazole has increased from $33 \%$ to $76.8 \%$ during the previous 10 years in Iran. ${ }^{5,13,22}$ This may also have contributed to the failure of this regimen in the country. 
Table 4: The efficacy of bismuth and metronidazole-containing quadruple therapy for $H$. pylori eradication

\begin{tabular}{|c|c|c|c|c|c|c|c|c|}
\hline Year & City & Therapy & $\begin{array}{c}\text { Treatment } \\
\text { duration } \\
\text { (days) }\end{array}$ & $\begin{array}{c}\text { Number of } \\
\text { patients. }\end{array}$ & $\begin{array}{c}\text { Underlying } \\
\text { disease }\end{array}$ & $\begin{array}{c}\text { Eradication } \\
\text { assessment } \\
\text { method. }\end{array}$ & $\begin{array}{c}\text { Duration } \\
\text { from therapy } \\
\text { (week) }\end{array}$ & $\begin{array}{c}\text { Per-protocol } \\
\text { eradication rate }\end{array}$ \\
\hline 2006 & Tehran $^{25}$ & $\begin{array}{c}\text { OABM } \\
\text { (M: } 500 \text { BID) } \\
\text { OSBM } \\
\text { (M: } 500 \text { BID) }\end{array}$ & 10 & 120 & H. pylori $(+)$ & UBT & 6 & $\begin{array}{l}85.8 \\
92.8\end{array}$ \\
\hline 2000 & Tehran $^{46}$ & RABM & 14 & 53 & $\mathrm{DU}$ & UBT & 4 & 52 \\
\hline 2001 & Tehran $^{49}$ & RTBM & 14 & 73 & DU & UBT & 8 & 73 \\
\hline 2006 & Semnan $^{47}$ & $\begin{array}{c}\text { OABM } \\
\text { (M: } 500 \text { BID) }\end{array}$ & 14 & 63 & H. pylori $(+)$ & UBT & 4 & 75.7 \\
\hline 2007 & Tehran $^{45}$ & $\begin{array}{c}\text { OABM } \\
\text { (M: } 500 \text { BID) }\end{array}$ & 14 & 107 & PUD & UBT & 8 & 83.1 \\
\hline 2009 & Tehran $^{44}$ & $\begin{array}{c}\text { OABM } \\
\text { (M: } 500 \text { BID) }\end{array}$ & 14 & 30 & H. pylori $(+)$ & UBT & 8 & 69 \\
\hline 2010 & Rasht $^{27}$ & $\begin{array}{c}\text { OABM } \\
\text { (M: } 500 \text { BID) }\end{array}$ & 14 & 107 & NUD & $\begin{array}{c}\text { Stool } \\
\text { Antigen }\end{array}$ & 8 & 85.7 \\
\hline 2012 & Tehran $^{48}$ & $\begin{array}{c}\text { OABM } \\
\text { (M: } 500 \text { BID) }\end{array}$ & 14 & 27 & H. pylori $(+)$ & UBT & 4 & 67.8 \\
\hline 2013 & Tehran $^{33}$ & $\begin{array}{c}\text { OABM } \\
\text { (M: } 500 \text { BID) }\end{array}$ & 14 & 110 & PUD & UBT & 6 & 56 \\
\hline 2013 & $\begin{array}{l}\text { Bandar } \\
\text { Abas }^{43}\end{array}$ & $\begin{array}{c}\text { OABM } \\
\text { (A: } 500 \text { TID) } \\
\text { (M: } 250 \text { TID) }\end{array}$ & 14 & 100 & H. pylori $(+)$ & UBT & 4 & 82.3 \\
\hline 2015 & $\mathrm{Ahvaz}^{30}$ & $\begin{array}{c}\text { OABM } \\
\text { (M: } 500 \text { BID) } \\
\text { OTBM } \\
\text { (T: } 500 \text { BID) }\end{array}$ & 14 & $\begin{array}{l}100 \\
100\end{array}$ & H. pylori $(+)$ & UBT & 8 & $\begin{array}{l}77.7 \\
84.4\end{array}$ \\
\hline
\end{tabular}

O: Omeprazole, Amox: Amoxicillin, B: Bismuth subcitrate, Tetra: Tetracycline, M: Metronidazole, S: Ampi-Sulbactam, DU: Duodenal ulcer, PUD: peptic ulcer disease, NUD: non-ulcer dyspepsia, UBT: urease breath test BID: twice daily, TDS: three times daily

\section{Bismuth-Furazolidone Quadruple Therapies:}

Furazolidone has been used in combination with bismuth in several studies in Iran. The first study was conducted in 2007 by Daghaghzadeh and colleagues. They evaluated the efficacy of 7-day bismuth-furazolidone quadruple therapy on 87 patients and reported $84.8 \%$ per-protocol eradication rate. ${ }^{50}$ Further studies evaluated the efficacy of the same regimen with longer duration of therapy. Two studies assessed the efficacy of 10-day bismuth plus furazolidone-containing quadruple therapy, which both reported acceptable eradication rates. ${ }^{28,38}$ Also, nine other studies evaluated the efficacy of 14-day therapy, of them six studies reported ideal eradication rates..$^{30,40,41,45,46,50-52}$ However, they were mostly accompanied by severe side effects of the treatment (table 5).

\section{Bismuth-Clarithromycin Quadruple Therapy:}

Bismuth plus clarithromycin quadruple therapy has also been used in 10-day or 14-day regimens. The only study that assessed the efficacy of 10-day regimen reported sub-optimal $H$. pylori eradication rate,,$^{53}$ but two out of three 14-day regimens could achieve ideal eradication rates. ${ }^{49,51,54}$ However, in one of these two studies, $13 \%$ of the patients reported severe adverse effects of the therapy ${ }^{51}$ (table 5).

\section{Sequential Therapy:}

Sequential therapy is a novel $H$. pylori eradication regimen, which contains a PPI plus amoxicillin during the first half of therapy and the PPI + clarithromycin + metronidazole or tinidazole just during the second half. Three studies have evaluated the efficacy of sequential therapies in Iran, ${ }^{27,55,56}$ but only one study reported acceptable $H$. pylori eradication rate, ${ }^{56}$ (table 6). On the other hand, $6 \%$ of the patients in the latter study reported severe adverse effects of the drugs. These results are in concordance 
Table 5: The efficacy of Bismuth plus Furazolidone- or Clarithromycin-containing quadruple therapies for $\boldsymbol{H}$. pylori eradication

\begin{tabular}{|c|c|c|c|c|c|c|c|c|}
\hline Year & City & Therapy & $\begin{array}{c}\text { Treatment } \\
\text { duration } \\
\text { (days) }\end{array}$ & $\begin{array}{l}\text { Number of } \\
\text { patients. }\end{array}$ & $\begin{array}{l}\text { Underlying } \\
\text { disease }\end{array}$ & $\begin{array}{c}\text { Eradication } \\
\text { assessment } \\
\text { method. }\end{array}$ & $\begin{array}{c}\text { Duration } \\
\text { from therapy } \\
\text { (week) }\end{array}$ & $\begin{array}{c}\text { Per-protocol } \\
\text { eradication rate }\end{array}$ \\
\hline 2007 & Isfahan $^{50}$ & $\mathrm{OABF}$ & 7 & 78 & H. pylori $(+)$ & UBT & 4 & 84.8 \\
\hline 2010 & Tehran ${ }^{28}$ & $\begin{array}{l}\text { OABM-F } \\
\text { OABC-F }\end{array}$ & $\begin{array}{c}10 \\
\text { (M: 5, F: } 5 \text {, } \\
\text { C: } 5 \text { ) }\end{array}$ & $\begin{array}{l}103 \\
103\end{array}$ & PUD & UBT & 8 & $\begin{array}{l}91.3 \\
88.7\end{array}$ \\
\hline 2015 & $\operatorname{Sari}^{38}$ & $\begin{array}{c}\text { OABF } \\
\text { OABM-F }\end{array}$ & $\begin{array}{c}10 \\
(\mathrm{M}: 5, \mathrm{~F}: 5)\end{array}$ & $\begin{array}{l}120 \\
120\end{array}$ & PUD & UBT & 8 & $\begin{array}{l}86.6 \\
82.5\end{array}$ \\
\hline 2000 & Tehran $^{46}$ & RABF & 14 & 53 & DU & UBT & 4 & 82 \\
\hline 2001 & Tehran $^{51}$ & $\mathrm{OABF}$ & 14 & 63 & DU & UBT & 12 & 90 \\
\hline 2004 & $\mathrm{Sari}^{40}$ & $\begin{array}{c}\text { OABF } \\
\text { (F: } 100 \mathrm{BID}) \\
\text { OABF } \\
\text { (F: } 200 \mathrm{BID})\end{array}$ & $\begin{array}{l}14 \\
14\end{array}$ & $\begin{array}{l}50 \\
50\end{array}$ & DU & UBT & 12 & $\begin{array}{l}72 \\
92\end{array}$ \\
\hline 2007 & Isfahan $^{50}$ & OABF & 14 & 78 & H. pylori $(+)$ & UBT & 4 & 82.6 \\
\hline 2007 & Tehran ${ }^{45}$ & $\begin{array}{c}\text { OABF } \\
\text { OABF-M }\end{array}$ & $\begin{array}{c}14 \\
(\mathrm{~F}: 7, \mathrm{M}: 7)\end{array}$ & $\begin{array}{l}104 \\
103\end{array}$ & PUD & UBT & 8 & $\begin{array}{l}95.2 \\
95.3\end{array}$ \\
\hline 2009 & Shiraz $^{34}$ & $\mathrm{OABF}$ & 14 & 69 & H. pylori $(+)$ & UBT & $4-6$ & 56 \\
\hline 2011 & Ghom $^{41}$ & OABF & 14 & 43 & H. pylori $(+)$ & UBT & 12 & 85.3 \\
\hline 2012 & $\operatorname{Sar}^{40}$ & $\mathrm{OABF}$ & 14 (F: 7) & 80 & PUD & UBT & 12 & 90.2 \\
\hline 2012 & $\operatorname{Sari}^{56}$ & $\mathrm{OABF}$ & 14 (F: 7) & 124 & PUD & UBT & 8 & 88.7 \\
\hline 2015 & Tehran $^{53}$ & $\mathrm{OABC}$ & 10 & 60 & H. pylori $(+)$ & UBT & 8 & 65.2 \\
\hline 2001 & Tehran $^{49}$ & $\begin{array}{c}\text { OBCT } \\
\text { (C: } 250 \text { BID) }\end{array}$ & 14 & 73 & DU & UBT & 8 & 88 \\
\hline 2001 & Tehran $^{51}$ & $\mathrm{OABC}$ & 14 & 55 & DU & UBT & 12 & 90 \\
\hline 2013 & Isfahan $^{54}$ & $\begin{array}{c}\text { OABC } \\
\text { OABC }+ \\
\text { probiotic }\end{array}$ & 14 & 90 & PUD & UBT & 4 & $\begin{array}{l}82.1 \\
84.4\end{array}$ \\
\hline
\end{tabular}

O: Omeprazole, R: Ranitidine, Amox: Amoxicillin, B: Bismuth subcitrate, Tetra: Tetracycline, M: Metronidazole, C: Clarithromycin, F: Furazolidone, DU: Duodenal ulcer, PUD: Peptic ulcer disease, UBT: Urea breath test, BID: twice daily

Table 6: The efficacy of non-bismuth quadruple therapies for $\boldsymbol{H}$. pylori eradication

\begin{tabular}{|c|c|c|c|c|c|c|c|c|}
\hline Year & City & Therapy & $\begin{array}{c}\text { Treatment } \\
\text { duration } \\
\text { (days) }\end{array}$ & $\begin{array}{l}\text { Number of } \\
\text { patients. }\end{array}$ & $\begin{array}{l}\text { Underlying } \\
\text { disease }\end{array}$ & $\begin{array}{c}\text { Eradication } \\
\text { assessment } \\
\text { method. }\end{array}$ & $\begin{array}{c}\text { Duration } \\
\text { from therapy } \\
\text { (week) }\end{array}$ & $\begin{array}{c}\text { Per-protocol } \\
\text { eradication rate }\end{array}$ \\
\hline 2010 & $\operatorname{Rash}^{56}$ & Sequential & 14 & 107 & NUD & Stool Antigen & 8 & 81 \\
\hline 2012 & $\operatorname{Sari}^{35}$ & Sequential & 14 & 137 & PUD & UBT & 8 & 89.1 \\
\hline 2013 & $\operatorname{Sari}^{55}$ & Sequential & 14 & 199 & PUD & UBT & 8 & 79.9 \\
\hline 2013 & $\operatorname{Sari}^{58}$ & Hybrid & 14 & 197 & PUD & UBT & 8 & 92.9 \\
\hline 2015 & Sari $^{59}$ & Hybrid & $\begin{array}{l}10 \\
14\end{array}$ & $\begin{array}{l}124 \\
126\end{array}$ & PUD & UBT & 8 & $\begin{array}{l}83.8 \\
92.8\end{array}$ \\
\hline 2016 & Sari $^{59}$ & Hybrid & 14 & 100 & PUD & UBT & 8 & 89.3 \\
\hline 2016 & Sari $^{59}$ & Concomitant & 10 & 100 & PUD & UBT & 8 & 85.9 \\
\hline
\end{tabular}

PUD: Peptic ulcer disease, NUD: Non-ulcer dyspepsia, UBT: Urea breath test

with the results of a meta-analysis by Gatta and coworkers who included 5666 patients to receive sequential therapy. The overall per-protocol H. pylori eradication rate by the mentioned meta-analysis was $84.3 \%$, which was not ideal for first-line $H$. pylori eradication. $^{57}$ 


\section{Hybrid Therapy:}

Hybrid therapy is another novel $H$. pylori eradication regimen consisted of a PPI + amoxicillin during the first half of the treatment and concurrent administration of PPI + amoxicillin + clarithromycin + metronidazole during the second half of the treatment.

Up to now, only three studies have evaluated the effects of hybrid regimen for eradication of $H$. pylori in Iran and all have achieved acceptable eradication rates, ${ }^{55,58,59}$ (table 6). Also, data from most other countries have shown ideal $H$. pylori eradication rates by hybrid regimen. ${ }^{60}$ The success of this regimen seems to be related to concurrent administration of three antibiotics in the second half of treatment course.

\section{Concomitant Therapy:}

Another type of non-bismuth quadruple regimen is the concomitant therapy. It includes concurrent administration of a PPI + amoxicillin + clarithromycin + metronidazole during the entire treatment protocol.

Up to now, only one study has evaluated the efficacy of concomitant therapy in Iran. In 2016, Alhooei and colleagues evaluated the efficacy of 10-day concomitant therapy on 126 patients with peptic ulcer disease. They reported $85.9 \%$ per-protocol eradication rate, which is almost suitable..$^{59}$

Also, studies from other countries have mostly shown ideal $H$. pylori eradication by concomitant therapy. ${ }^{61-63}$ According to Maastricht V Consensus Report, concomitant therapy is the most effective non-bismuth quadruple therapy and can be used if the prevalence of dual resistant strains to clarithromycin and metronidazole is less than $15 \%$. Furthermore, the recommended duration of concomitant therapy is 14 days, unless shorter durations of therapies are proven to be effective locally. ${ }^{4}$ Accordingly, further studies with longer duration of treatment by concomitant regimen may achieve higher eradication rates in Iran.

\section{Quinolone-Containing Regimens:}

Up to now, only three studies have evaluated the efficacy of fluoroquinolone-containing regimens for H. pylori eradication; however, all of them reported sub-optimal eradication rates. In 2010, Aminian and co-workers assessed the effects of a 14-day triple therapy in which ciprofloxacin had been administered just during the first 7 days. They reported 70\% per-protocol eradication rate. ${ }^{27}$ Another study was conducted by Karbasi and colleagues in 2013. They divided 60 patients with $H$. pylori into two groups to receive pantoprazole-bismuth-ciprofloxacin with or without $\mathrm{N}$-acetyl cysteine. Per-protocol eradication rates were $60.7 \%$ and $70 \%$, respectively. ${ }^{64}$ Also, in 2015, Masoodi and others evaluated the effects of 10-day bismuth-based gemifloxacin-containing quadruple therapy. They reported $72.7 \%$ per-protocol eradication rate. ${ }^{53}$

In Iran, the rates of H. pylori resistance to fluoroquinolones, especially to ciprofloxacin has increased dramatically during the previous 5 years; playing an important role in the failure of this regimen. ${ }^{10,19}$

\section{Azithromycin-Containing Therapy:}

During the previous years, four studies have evaluated the efficacy of azithromycin-containing regimens for $H$. pylori eradication, but none of these regimens could achieve acceptable eradication rates. ${ }^{29,35,44,47}$ In 2006, Mousavi and colleagues assessed the efficacy of bismuth-based azithromycincontaining regimen in Semnan. ${ }^{47}$ Also, in 2009, a subsequent study evaluated the efficacy of the same regimen in Tehran. The H. pylori eradication rates were $78 \%$ and $68 \%$, respectively. ${ }^{44}$ On the other hand, two recent studies evaluated the effects of azithromycin-containing triple therapy. The perprotocol eradication rates were $75 \%$ and $77 \%$, respectively. ${ }^{29,35}$ Accordingly, azithromycin-containing therapies do not seem to be ideal options for firstline H. pylori eradication in Iran.

\section{Treatment Failure:}

As we have previously described, ${ }^{65}$ failure of $H$. pylori treatment depends on multiple factors related to both the bacterium and the host. In fact, the effects of antibiotics in vivo are not the same as those observed in vitro, because antibiotics must diffuse to the gastric mucosal layer where the bacteria reside. Moreover, low gastric $\mathrm{pH}$ may compromise antibiotic 
Table 7: The efficacy of second line therapies for $\mathrm{H}$. pylori eradication

\begin{tabular}{|c|c|c|c|c|c|}
\hline Year & City & First Regimen & Second Regimen & Number of Patients & Per-protocol Eradication Rate \\
\hline 2001 & Tehran $^{73}$ & OABM & OTBF & 80 & 90 \\
\hline 2003 & Tehran $^{74}$ & OABM & OABF & 90 & 78.7 \\
\hline 2010 & Isfahan $^{75}$ & OABM & $\begin{array}{l}\text { OABC } \\
\text { OAzBOf }\end{array}$ & $\begin{array}{l}110 \\
110\end{array}$ & $\begin{array}{l}74.7 \\
86.7\end{array}$ \\
\hline 2012 & $\operatorname{Sari}^{37}$ & Sequential & $\begin{array}{c}\text { OABF } \\
\text { (F: 7days) }\end{array}$ & 36 & 82.9 \\
\hline 2015 & $\operatorname{Rasht}^{52}$ & OABM & $\begin{array}{l}\text { OBTMOf } \\
\text { OABCT }\end{array}$ & $\begin{array}{l}104 \\
104\end{array}$ & $\begin{array}{c}86.7 \\
76 \\
\end{array}$ \\
\hline 2016 & $\operatorname{Sari}^{77}$ & $\begin{array}{l}\text { OABM } \\
\text { OABF }\end{array}$ & $\begin{array}{l}\mathrm{OABC} \\
\mathrm{OABC}\end{array}$ & $\begin{array}{l}32 \\
31\end{array}$ & $\begin{array}{c}87 \\
82.7\end{array}$ \\
\hline 2016 & $\mathrm{Sari}^{79}$ & $\begin{array}{l}\text { Non-bismuth } \\
\text { clarithromycin-containing }\end{array}$ & PAL & 61 & 91.8 \\
\hline
\end{tabular}

O: Omeprazole, Amox: Amoxicillin, B: Bismuth subcitrate, Tetra: Tetracycline, M: Metronidazole, C: Clarithromycin, F: Furazolidone, Of: Ofloxacin, Az: Azithromycin

activity. Most antibiotics have the greatest activity at neutral $\mathrm{pH}$; nevertheless, clarithromycin has especially the greatest activity at higher $\mathrm{pH}$ (around 8) and metronidazole has the greatest activity at lower $\mathrm{pH}$ (around 6). Thus, clarithromycin is the only antibiotic that benefits from a high $\mathrm{pH}$ caused by PPI. ${ }^{37}$ Furthermore, sometimes $H$. pylori transforms into coccoid shape, which keeps it from the effects of antibiotics. ${ }^{66}$ Also, some strains, including Cag Anegative strains and those carrying Vac As $2 \mathrm{~m} 2$ allele, show resistance to antibiotics. ${ }^{67}$ However, the most important factor influencing response to treatment is primary resistance to antibiotics, which is increasing all over the world due to extensive use of antibiotics. $^{68}$

Among host factors, compliance to treatment plays an important role. Patients may not completely adhere to treatment due to adverse effects or combination of multiple drugs in multiple daily doses. Besides, the patient's underlying disease also affects the $H$. pylori eradication rate. Some studies have shown that patients with non-ulcer dyspepsia have lower eradication rates compared with those with PUD. ${ }^{67,69}$

Since low gastric $\mathrm{pH}$ lowers the effects of antibiotics, PPIs are administered to increase gastric $\mathrm{pH}$. Most PPIs are metabolized by cytochrome P450 in the liver. Therefore, patients with extensive metabolizing do not attain sufficient PPI levels to achieve optimal $\mathrm{pH}$ level for antibiotic effects. ${ }^{70}$
Smoking is also another factor influencing the response to treatment. ${ }^{71}$ It reduces gastric mucosal blood flow and increases gastric acid secretion; therefore lowering antibiotics activity.

All the mentioned factors should be kept in mind in patients with treatment failure.

\section{Second-Line Treatment Regimens:}

The ideal second-line $H$. pylori eradication therapy is the regimen that can achieve $>80 \%$ per-protocol eradication rate. ${ }^{72}$ Few studies have addressed second-line therapies in Iran (table 7).

- In 2001, Sotoudehmanesh and colleagues evaluated the effects of 14-day OTBF (O: omeprazole, $\mathrm{T}$ : tetracycline, B: bismuth, F: furazolidone) on 80 patients who had previously failed treatment with 2 weeks of omeprazole + amoxicillin + bismuth + metronidazole (OABM) therapy. The per-protocol eradication rate was $90 \% .^{73}$

- In 2003, Ebrahimi-Daryani and co-workers conducted a study to evaluate the effects of 14-day bismuth- and furazolidone containing quadruple therapy on 90 patients who had failed treatment with metronidazole-based quadruple therapy. The per-protocol $H$. pylori eradication rate was $78.7 \% .^{74}$

- In 2010, 220 patients who had failed treatment with OABM were randomized to receive either OABC (C: clarithromycin) or OBAzOf (Az: azithromycin, Of: ofloxacin). Per-protocol eradication rates were $74.7 \%$ and $86.7 \%$, respectively. ${ }^{75}$ 
Table 8: Recommended treatment regimens for Helicobacter pylori eradication in Iran

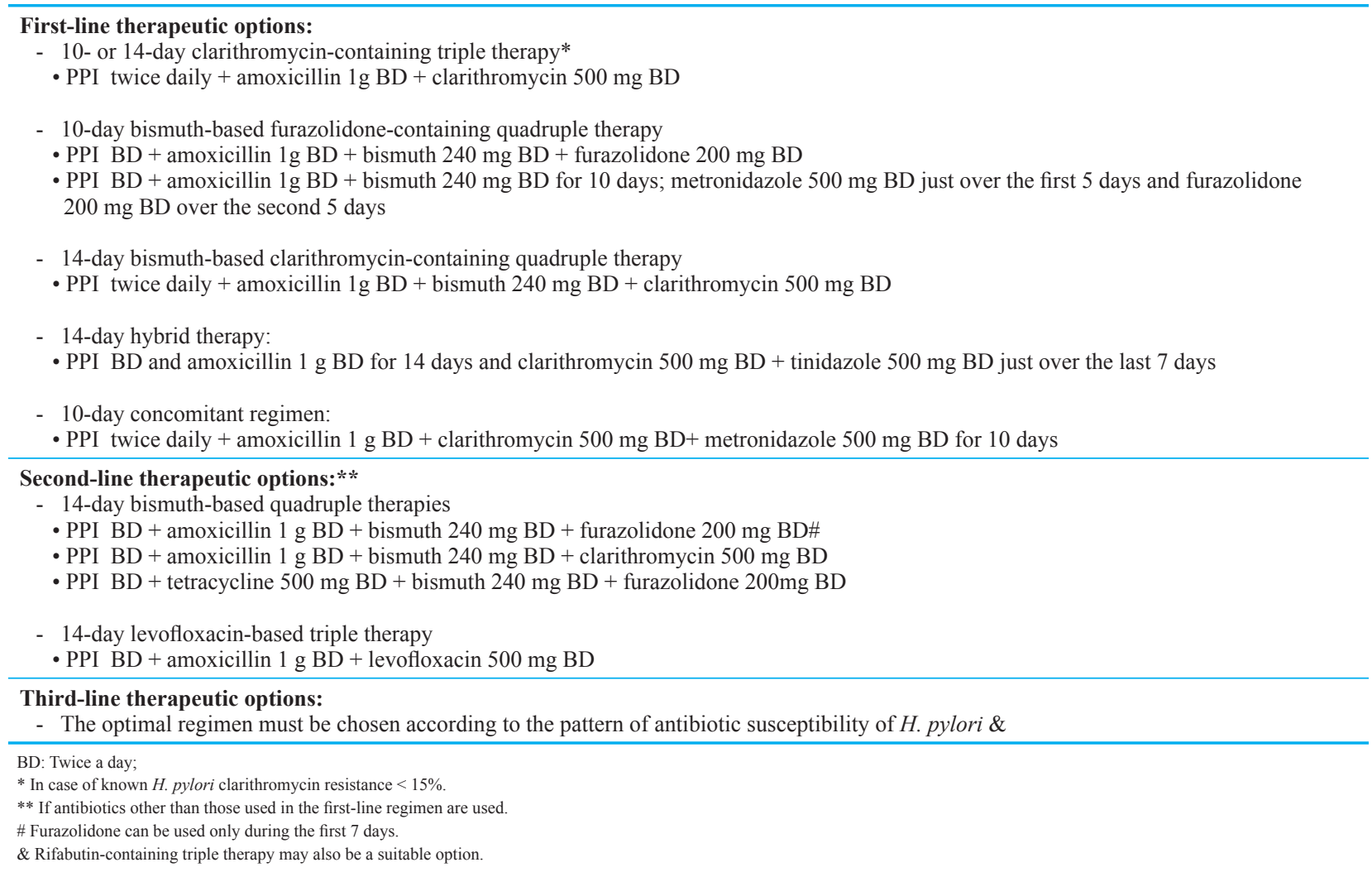

- In 2012, Fakheri and colleagues investigated the efficacy of a modified bismuth- and furazolidone-containing 14-day quadruple therapy after failure with classic sequential therapy. The regimen contained furazolidone only during the first 7 days. They achieved $82.9 \%$ per-protocol eradication rate. ${ }^{52}$

- In 2015, Mansour Ghanaei and others investigated the effects of two different 7-day quintuple therapies on 208 patients who had failed previous therapy with OABM regimen. The patients were randomly given OBTMOf or OABCTi (Ti: tinidazole). The per-protocol eradication rates were $86.7 \%$ and $76 \%$, respectively. ${ }^{76}$

- In 2016, Fakheri and colleagues assessed the efficacy of 14-day bismuth- and clarithromycincontaining quadruple therapy on two groups of patients who had failed previous therapy with OABF or OABM regimens. The eradication rates were $82.7 \%$ and $87 \%$, respectively. ${ }^{77}$

- Also, in 2017, Fakheri and co-workers evaluated the efficacy of 14-day levofloxacin-based triple therapy. They achieved $91.8 \%$ per-protocol eradication rate. Of note, the frequency of severe adverse effects was very low $(3.2 \%){ }^{78}$

According to Maastricht V Consensus Report, either a bismuth quadruple therapy or a fluoroquinolone-containing triple or quadruple therapy are recommended after failure of standard triple therapy or even after failure of a non-bismuth quadruple regimen. ${ }^{4}$ The results of studies performed in Iran are in concordance with the statements of the Maastricht V Consensus Report.

\section{Third-Line Treatment Regimens:}

In Iran, no study has dealt with patients who have failed second-line $H$. pylori eradication regimens. According to Maastricht V Consensus Report, after failure of second-line treatment, regimens should be chosen according to the results of culture and susceptibility testing or molecular determination of genotype resistance. ${ }^{4}$ However, if culture is not available, fluoroquinolone-containing regimen is 
recommended after failure of a second-line treatment with bismuth-containing quadruple therapy. However, in countries with a known high fluoroquinolones resistance, or in case of failure with second-line fluoroquinolone-containing therapies, a combination of bismuth with different antibiotics or a rifabutin-containing rescue therapy should be considered. ${ }^{4}$

\section{Limitations:}

The present narrative review has some limitations, including the unavailability of data about the results of $H$. pylori culture in each study, heterogeneity of studies in the number of patients, doses of antibiotics, duration of therapies, kinds of PPIs, and the underlying peptic disorders. These could lead to discrepancies in eradication rates, because higher doses and longer duration of therapy can increase the success rates and the underlying peptic disorder would influence the rate of $H$. pylori eradication. Furthermore, our study was restricted to English reports.

In conclusion, according to our study, among first-line eradication options, bismuth-based furazolidone- or clarithromycin-containing quadruple therapies, hybrid regimen, and concomitant therapy seem to be appropriate options. Also, 10- or 14-day clarithromycin-containing triple therapy can be used if local $H$. pylori resistance to clarithromycin is known to be less than $15 \%$ (table 8 ).

For second-line $H$. pylori eradication, bismuthbased quadruple therapies and 14-day levofloxacinbased triple therapy seem to be suitable options, provided that antibiotics other than those had been used in the first-line regimen. Third-line $H$. pylori eradication regimens have not been addressed in Iranian studies. However, most guidelines recommend treatment according to the results of culture and susceptibility testing (table 8).

Although we limited our investigation to $H$. pylori eradication regimens in Iran, the results are transferrable to any region as long as the patterns of antibiotic resistance are the same.

\section{ETHICAL APPROVAL}

There is nothing to be declared.

\section{CONFLICT OF INTEREST}

The author declares no conflict of interest related to this work.

\section{REFERENCES}

1. Go MF. Review article: natural history and epidemiology of Helicobacter pylori infection. Aliment Pharmacol Ther 2002;16 Suppl 1:3-15. doi: 10.1046/j.13652036.2002.0160s1003.x.

2. Moosazadeh M, Lankarani KB, Afshari M. Meta-analysis of the Prevalence of Helicobacter Pylori Infection among Children and Adults of Iran. Int J Prev Med 2016;7:48. doi: 10.4103/2008-7802.177893.

3. Malekzadeh R, Sotoudeh M, Derakhshan MH, Mikaeli J, Yazdanbod A, Merat S, et al. Prevalence of gastric precancerous lesions in Ardabil, a high incidence province for gastric adenocarcinoma in the northwest of Iran. $J$ Clin Pathol 2004;57:37-42. doi: 10.1136/jcp.57.1.37.

4. Malfertheiner P, Megraud F, O'Morain CA, Gisbert JP, Kuipers EJ, Axon AT, et al. Management of Helicobacter pylori infection-the Maastricht V/Florence Consensus Report. Gut 2017;66:6-30. doi: 10.1136/gutjnl-2016-312288.

5. Safaralizadeh R, Siavoshi F, Malekzadeh R, Akbari MR, Derakhshan MH, Sohrabi MR, et al. Antimicrobial effectiveness of furazolidone against metronidazole-resistant strains of Helicobacter pylori. East Mediterr Health J 2006;12:286-93.

6. Majlesi A, Sayedin Khorasani M, Khalilian AR, Aslani MM, Jaefari M, Alikhani MY. A. Antibiotic Susceptibility of Helicobacter pylori Clinical Isolates in Hamadan, West of Iran. Int J Entric Pathog 2013;1:e9344. doi: 10.17795/ijep9344.

7. Mohammadi M, Doroud D, Mohajerani N, Massarrat S. Helicobacter pylori antibiotic resistance in Iran. World J Gastroenterol 2005;11:6009-13. doi: 10.3748/wjg.v11.i38.6009.

8. Siavoshi F, Saniee P, Latifi-Navid S, Massarrat S, Sheykholeslami A. Increase in resistance rates of $H$. pylori isolates to metronidazole and tetracycline--comparison of three 3-year studies. Arch Iran Med 2010;13:177-87.

9. Zendedel A, Moradimoghadam F, Almasi V, Zivarifar H. Antibiotic resistance of Helicobacter pylori in Mashhad, Iran. J Pak Med Assoc 2013;63:336-9.

10. Shokrzadeh L, Jafari F, Dabiri H, Baghaei K, Zojaji H, Alizadeh AH, et al. Antibiotic susceptibility profile of Helicobacter pylori isolated from the dyspepsia patients in Tehran, Iran. Saudi J Gastroenterol 2011;17:261-4. doi: 10.4103/1319-3767.82581.

11. Abadi AT, Taghvaei T, Mobarez AM, Carpenter BM, Merrell DS. Frequency of antibiotic resistance in Helicobacter pylori strains isolated from the northern population of Iran. J Microbiol 2011;49:987-93. doi: 10.1007/ s12275-011-1170-6.

12. Talebi Bezmin Abadi A, Ghasemzadeh A, Taghvaei T, Mobarez AM. Primary resistance of Helicobacter pylori 
to levofloxacin and moxifloxacine in Iran. Intern Emerg Med 2012;7:447-52. doi: 10.1007/s11739-011-0563-1.

13. Milani M, Ghotaslou R, Akhi MT, Nahaei MR, Hasani A, Somi MH, et al. The status of antimicrobial resistance of Helicobacter pylori in Eastern Azerbaijan, Iran: comparative study according to demographics. $J$ Infect Chemother 2012;18:848-52. doi: 10.1007/s10156-012-0425-4.

14. Siavoshi F, Safari F, Doratotaj D, Khatami GR, Fallahi $\mathrm{GH}$, Mirnaseri MM. Antimicrobial resistance of Helicobacter pylori isolates from Iranian adults and children. Arch Iran Med 2006;9:308-14.

15. Sadeghifard N, Seidnazari T, Ghafourian S, Soleimani M, Maleki A, Qomi MA, et al. Survey in Iran of clarithromycin resistance in Helicobacter pylori isolates by PCR-RFLP. Southeast Asian J Trop Med Public Health 2013;44:89-95.

16. Maleknejad S, Mojtahedi A, Safaei-Asl A, Taghavi Z, Kazemnejad E. Primary Antibiotic Resistance to $\mathrm{He}$ licobacter pylori Strains Isolated From Children in Northern Iran: A Single Center Study. Iran J Pediatr 2015;25:e2661. doi: 10.5812/ijp.2661.

17. Keshavarz Azizi Raftar S, Moniri R, Saffari M, Razavi Zadeh M, Arj A, Mousavi SG, et al. The Helicobacter pylori resistance rate to clarithromycin in Iran. Microb Drug Resist 2015;21:69-73. doi: 10.1089/mdr.2014.0104.

18. Khademi F, Faghri J, Poursina F, Esfahani BN, Moghim $\mathrm{S}$, Fazeli H, et al. Resistance pattern of Helicobacter pylori strains to clarithromycin, metronidazole, and amoxicillin in Isfahan, Iran. $J$ Res Med Sci 2013;18:1056-60.

19. Shokrzadeh L, Alebouyeh M, Mirzaei T, Farzi N, Zali MR. Prevalence of multiple drug-resistant Helicobacter pylori strains among patients with different gastric disorders in Iran. Microb Drug Resist 2015;21:105-10. doi: 10.1089/mdr.2014.0081.

20. Khademi F, Poursina F, Hosseini E, Akbari M, Safaei HG. Helicobacter pylori in Iran: A systematic review on the antibiotic resistance. Iran J Basic Med Sci 2015;18:2-7.

21. Khashei R, Dara M, Bazargani A, Bagheri Lankarani K, Taghavi A, Moeini M, et al. High rate of A2142G point mutation associated with clarithromycin resistance among Iranian Helicobacter pylori clinical isolates. APMIS 2016;124:787-93. doi: 10.1111/apm.12567.

22. Moradi Golrokhi M, Fakheri H, Haghshenas MR, M. A. The determination of antibiotic resistance of Helicobacter pylori isolated from patients living in north of Iran (Sari). Univ J Microbiol Res 2016;4:6-10.

23. Fallone CA, Chiba N, van Zanten SV, Fischbach L, Gisbert JP, Hunt RH, et al. The Toronto Consensus for the Treatment of Helicobacter pylori Infection in Adults. Gastroenterology 2016;151:51-69 e14. doi: 10.1053/j. gastro.2016.04.006.

24. Malekzadeh R, Merat S, Derakhshan MH, Siavoshi F, Yazdanbod A, Mikaeli J, et al. Low Helicobacter pylori eradication rates with 4- and 7-day regimens in an Iranian population. J Gastroenterol Hepatol 2003;18:13-7. doi: 10.1046/j.1440-1746.2003.02897.x.
25. Mirbagheri SA, Hasibi M, Abouzari M, Rashidi A. Triple, standard quadruple and ampicillin-sulbactam-based quadruple therapies for $H$. pylori eradication: a comparative three-armed randomized clinical trial. World J Gastroenterol 2006;12:4888-91. doi: 10.3748/wjg.v12.i30.4888.

26. Mirzaee V, Rezahosseini O. Randomized control trial: Comparison of Triple Therapy plus Probiotic Yogurt vs. Standard Triple Therapy on Helicobacter Pylori Eradication. Iran Red Crescent Med J 2012;14:657-66.

27. Aminian K, Farsad F, Ghanbari A, Fakhreih S, Hasheminasab SM. A randomized trial comparing four $\mathrm{He}$ licobacter pylori eradication regimens: standard triple therapy, ciprofloxacin based triple therapy, quadruple and sequential therapy. Trop Gastroenterol 2010;31:303-7.

28. Riahizadeh S, Malekzadeh R, Agah S, Zendehdel N, Sotoudehmanesh R, Ebrahimi-Dariani N, et al. Sequential metronidazole-furazolidone or clarithromycin-furazolidone compared to clarithromycin-based quadruple regimens for the eradication of Helicobacter pylori in peptic ulcer disease: a double-blind randomized controlled trial. Helicobacter 2010;15:497-504. doi: 10.1111/j.1523-5378.2010.00798.x.

29. Sarkeshikian SS, Iranikhah A, Ghadir MR. Azithromycin based triple therapy versus standard clarithromycin based triple therapy in eradication of Helicobacter pylori infection in Iran: a randomized controlled clinical trial. Turk $J$ Gastroenterol 2013;24:10-4.

30. Masjedizadeh A, Zaeemzadeh N, Mard SA, Vanani GS. Comparing the efficacy of four different protocols for eradicating of Helicobacter pylori infection in Ahvaz, southwest Iran. Prz Gastroenterol 2015;10:94-9. doi: $10.5114 /$ pg.2015.49001.

31. Masjedizadeh A, Hajiani E, Hashemi J, Shayesteh A, S. Prospective Randomized Trial of Esomeprazole versus Lansoprazole and Omeprazole Based Triple Therapy for H. Pylori Eradication in an Iranian Population. Shiraz E Med J 2012;13:15-168.

32. Keshavarz AA, Bashiri H, Rahbar M. Omeprazole-based triple therapy with low-versus high-dose of clarithromycin plus amoxicillin for $H$ pylori eradication in Iranian population. World J Gastroenterol 2007;13:930-3.

33. Seyedmajidi S, Mirsattari D, Zojaji H, Zanganeh E, Seyyedmajidi M, Almasi S, et al. Penbactam for Helicobacter pylori eradication: a randomised comparison of quadruple and triple treatment schedules in an Iranian population. Arab J Gastroenterol 2013;14:1-5. doi: 10.1016/j.ajg.2012.12.004.

34. Taghavi SA, Jafari A, Eshraghian A. Efficacy of a new therapeutic regimen versus two routinely prescribed treatments for eradication of Helicobacter pylori: a randomized, double-blind study of doxycycline, co-amoxiclav, and omeprazole in Iranian patients. Dig Dis Sci 2009;54:599-603. doi: 10.1007/s10620-008-0374-z.

35. Khoshnood A, Hakimi P, Salman-Roghani H, Reza Mirjalili M. Replacement of clarithromycin with azithromycin in triple therapy regimens for the eradication of $\mathrm{He}$ licobacter pylori: A randomized clinical trial. J Med Life 2014;7:254-9. 
36. Ehsani-Ardakani MJ, Sedaghat M, Eslami G, Mohaghegh Shalmani H. The Helicobacter pylori eradication in the group receiving standard -dose and group continue taking amoxicillin for 4 weeks; a clinical trial study. Gastroenterol Hepatol Bed Bench 2015;8:S54-9.

37. Morini S, Zullo A, Hassan C, Lorenzetti R, Stella F, Martini MT. Gastric cardia inflammation: role of Helicobacter pylori infection and symptoms of gastroesophageal reflux disease. Am J Gastroenterol 2001;96:2337-40. doi:10.1111/j.1572-0241.2001.04038.x

38. Mokhtare M, Hosseini V, Tirgar Fakheri H, Maleki I, Taghvaei T, Valizadeh SM, et al. Comparison of quadruple and triple Furazolidone containing regimens on eradication of helicobacter pylori. Med J Islam Repub Iran 2015;29:195.

39. Hosseini V, Mokhtare M, Gholami M, Taghvaei T, Maleki I, Valizadeh M, et al. A Comparison between Moderate- and High-dose Furazolidone in Triple Regimens for Helicobacter pylori Eradication in Iran. Middle East $J$ Dig Dis 2014;6:195-202.

40. Fakheri H, Merat S, Hosseini V, Malekzadeh R. Low-dose furazolidone in triple and quadruple regimens for Helicobacter pylori eradication. Aliment Pharmacol Ther 2004;19:89-93.

41. Ghadir MR, Shafaghi A, Iranikhah A, Pakdin A, Joukar F, Mansour-Ghanaei F. Furazolidone, amoxicillin and omeprazole with or without bismuth for eradication of Helicobacter pylori in peptic ulcer disease. Turk $J$ Gastroenterol 2011;22:1-5.

42. Roghani HS, Massarrat S, Shirekhoda M, Butorab Z. Effect of different doses of furazolidone with amoxicillin and omeprazole on eradication of Helicobacter pylori. J Gastroenterol Hepatol 2003;18:778-82. doi: 10.1046/j.1440-1746.2003.03058.x.

43. Masoodi M, Panahian M, Rezadoost A, Heidari A. Eradication Rate of Helicobacter pylori using a Two-week Quadruple Therapy: A Report from Southern Iran. Middle East J Dig Dis 2013;5:81-5.

44. Agah S, Shazad B, Abbaszadeh B. Comparison of azithromycin and metronidazole in a quadruple-therapy regimen for Helicobacter pylori eradication in dyspepsia. Saudi J Gastroenterol 2009;15:225-8. doi: 10.4103/1319-3767.56091.

45. Khatibian M, Ajvadi Y, Nasseri-Moghaddam S, et al. Furazolidone-based, metronidazole-based, or a combination regimen for eradication of Helicobacter pylori in peptic ulcer disease. Arch Iran Med 2007;10:161-7.

46. Malekzadeh R, Ansari R, Vahedi H, Siavoshi F, Alizadeh BZ, Eshraghian MR, et al. Furazolidone versus metronidazole in quadruple therapy for eradication of Helicobacter pylori in duodenal ulcer disease. Aliment Pharmacol Ther 2000;14:299-303. doi: 10.1046/j.1365-2036.2000.00709.x.

47. Mousavi S, Toussy J, Yaghmaie S, Zahmatkesh M. Azithromycin in one week quadruple therapy for $\mathrm{H}$ pylori eradication in Iran. World J Gastroenterol 2006;12:45536. doi: 10.3748/wjg.v12.i28.4553.

48. Shidfar F, Agah S, Ekhlasi G, Salehpour A, Ghourchian S. Lycopene an adjunctive therapy for Helicobacter pylo- ri eradication: a quasi-control trial. $J$ Complement Integr Med 2012;9:Article 14. doi: 10.1515/1553-3840.1588.

49. Sotudehmanesh R, Malekzadeh R, Fazel A, Massarrat S, Ziad-Alizadeh B, Eshraghian MR. A randomized controlled comparison of three quadruple therapy regimens in a population with low Helicobacter pylori eradication rates. J Gastroenterol Hepatol 2001;16:264-8. doi: 10.1046/j.1440-1746.2001.02416.x.

50. Daghaghzadeh H, Emami MH, Karimi S, Raeisi M. Oneweek versus two-week furazolidone-based quadruple therapy as the first-line treatment for Helicobacter pylori infection in Iran. J Gastroenterol Hepatol 2007;22:1399403. doi: 10.1111/j.1440-1746.2007.05029.x.

51. Fakheri H, Malekzadeh R, Merat S, Khatibian M, Fazel A, Alizadeh BZ, et al. Clarithromycin vs. furazolidone in quadruple therapy regimens for the treatment of Helicobacter pylori in a population with a high metronidazole resistance rate. Aliment Pharmacol Ther 2001;15:411-6. doi: 10.1046/j.1365-2036.2001.00931.x.

52. Fakheri H, Bari Z, Sardarian H. A modified bismuthcontaining quadruple therapy including a short course of furazolidone for Helicobacter pylori eradication after sequential therapy failure. Helicobacter 2012;17:264-8. doi: 10.1111/j.1523-5378.2012.00946.x.

53. Masoodi M, Talebi-Taher M, Tabatabaie K, Khaleghi S, Faghihi AH, Agah S, et al. Clarithromycin vs. Gemifloxacin in Quadruple Therapy Regimens for Empiric Primary Treatment of Helicobacter pylori Infection: A Randomized Clinical Trial. Middle East J Dig Dis 2015;7:88-93.

54. Shavakhi A, Tabesh E, Yaghoutkar A, Hashemi H, Tabesh F, Khodadoostan M, et al. The effects of multistrain probiotic compound on bismuth-containing quadruple therapy for Helicobacter pylori infection: a randomized placebo-controlled triple-blind study. Helicobacter 2013;18:280-4. doi: 10.1111/hel.12047.

55. Sardarian H, Fakheri H, Hosseini V, Taghvaei T, Maleki I, Mokhtare M. Comparison of hybrid and sequential therapies for Helicobacter pylori eradication in Iran: a prospective randomized trial. Helicobacter 2013;18:129-34. doi: 10.1111/hel.12017.

56. Fakheri H, Taghvaei T, Hosseini V, Bari Z. A comparison between sequential therapy and a modified bismuthbased quadruple therapy for Helicobacter pylori eradication in Iran: a randomized clinical trial. Helicobacter 2012;17:43-8. doi: 10.1111/j.1523-5378.2011.00896.x.

57. Gatta L, Vakil N, Vaira D, Scarpignato C. Global eradication rates for Helicobacter pylori infection: systematic review and meta-analysis of sequential therapy. $B M J$ 2013;347:f4587. doi: 10.1136/bmj.f4587.

58. Metanat HA, Valizadeh SM, Fakheri H, Maleki I, Taghvaei T, Hosseini V, et al. Comparison Between 10- and 14-Day Hybrid Regimens for Helicobacter pylori Eradication: A Randomized Clinical Trial. Helicobacter 2015;20:299-304. doi: 10.1111/hel.12202.

59. Alhooei S, Tirgar Fakheri H, Hosseini V, Maleki I, Taghvaei $\mathrm{T}$, Valizadeh SM, et al. A Comparison between Hy- 
brid and Concomitant Regimens for Helicobacter Pylori Eradication: A Randomized Clinical Trial. Middle East $J$ Dig Dis 2016;8:219-25.

60. Hsu PI, Wu DC, Wu JY, Graham DY. Modified sequential Helicobacter pylori therapy: proton pump inhibitor and amoxicillin for 14 days with clarithromycin and metronidazole added as a quadruple (hybrid) therapy for the final 7 days. Helicobacter 2011;16:139-45. doi: 10.1111/j.1523-5378.2011.00828.x.

61. Wu DC, Hsu PI, Wu JY, Opekun AR, Kuo CH, Wu IC, et al. Sequential and concomitant therapy with four drugs is equally effective for eradication of $H$ pylori infection. Clin Gastroenterol Hepatol 2010;8:36-41. doi: 10.1016/j.cgh.2009.09.030.

62. Gisbert JP, Calvet X. Update on non-bismuth quadruple (concomitant) therapy for eradication of Helicobacter pylori. Clin Exp Gastroenterol 2012;5:23-34. doi: 10.2147/ CEG.S25419.

63. Zullo A, Scaccianoce G, De Francesco V, Ruggiero V, D'Ambrosio P, Castorani L, et al. Concomitant, sequential, and hybrid therapy for $H$. pylori eradication: a pilot study. Clin Res Hepatol Gastroenterol 2013;37:647-50. doi: 10.1016/j.clinre.2013.04.003.

64. Karbasi A, Hossein Hosseini S, Shohrati M, Amini M, Najafian B. Effect of oral N-acetyl cysteine on eradication of Helicobacter pylori in patients with dyspepsia. Minerva Gastroenterol Dietol 2013;59:107-12.

65. Fakheri H, Bari Z, Aarabi M, Malekzadeh R. Helicobacter pylori eradication in West Asia: a review. World journal of gastroenterology 2014;20:10355-67. doi: 10.3748/wjg.v20.i30.10355.

66. Kusters JG, Gerrits MM, Van Strijp JA, VandenbrouckeGrauls CM. Coccoid forms of Helicobacter pylori are the morphologic manifestation of cell death. Infect Immun 1997; 65:3672-9.

67. van Doorn LJ, Schneeberger PM, Nouhan N, Plaisier AP, Quint WG, de Boer WA. Importance of Helicobacter pylori cagA and vacA status for the efficacy of antibiotic treatment. Gut 2000;46:321-6. doi: 10.1136/gut.46.3.321.

68. Graham DY, Fischbach L. Helicobacter pylori treatment in the era of increasing antibiotic resistance. Gut 2010;59:1143-53. doi: 10.1136/gut.2009.192757.

69. Gisbert JP. Helicobacter pylori eradication therapy is more effective in peptic ulcer than in non-ulcer dyspepsia. Gut 2001;46:321-6.

70. Hokari K, Sugiyama T, Kato M, Saito M, Miyagishima T, Kudo M, et al. Efficacy of triple therapy with rabeprazole for Helicobacter pylori infection and CYP2C19 genetic polymorphism. Aliment Pharmacol Ther 2001;15:147984. doi: 10.1046/j.1365-2036.2001.01063.x.

71. Labenz J, Stolte M, Blum AL, et al. Intragastric acidity as a predictor of the success of Helicobacter pylori eradication: a study in peptic ulcer patients with omeprazole and amoxicillin. Gut 1995;37:39-43. doi: 10.1136/gut.37.1.39.

72. Boyanova L, Mitov I. Geographic map and evolution of primary Helicobacter pylori resistance to antibacterial agents. Expert Rev Anti Infect Ther 2010;8:59-70. doi: 10.1586/eri.09.113.

73. Sotoudehmanesh R, Malekzadeh R, Vahedi H, Dariani NE, Asgari AA, Massarrat S. Second-line Helicobacter pylori eradication with a furazolidone-based regimen in patients who have failed a metronidazole-based regimen. Digestion 2001;64:222-5. doi: 10.1159/000048865.

74. Ebrahimi-Dariani N, Mirmomen S, Mansour-Ghanaei F, Noormohammadpoor P, Sotodehmanesh R, Haghpanah $\mathrm{B}$, et al. The efficacy of furazolidone-based quadruple therapy for eradication of Helicobacter pylori infection in Iranian patients resistant to metronidazole-based quadruple therapy. Med Sci Monit 2003;9:PI105-8.

75. Minakari M, Davarpanah Jazi AH, Shavakhi A, Moghareabed N, Fatahi F. A randomized controlled trial: efficacy and safety of azithromycin, ofloxacin, bismuth, and omeprazole compared with amoxicillin, clarithromycin, bismuth, and omeprazole as second-line therapy in patients with Helicobacter pylori infection. Helicobacter 2010;15:154-9. doi: 10.1111/j.1523-5378.2009.00739.x.

76. Mansour-Ghanaei F, Joukar F, Naghipour MR, Forouhari A, Saadat SM. Seven-day quintuple regimen as a rescue therapy for Helicobacter pylori eradication. World J Gastroenterol 2015;21:661-6. doi: 10.3748/wjg.v21.i2.661.

77. Fakheri H, Bakhshi Z, Bari Z, Alhooei S. Effects of Clarithromycin-Containing Quadruple Therapy on Helicobacter Pylori Eradication after Nitroimidazole-Containing Quadruple Therapy Failure. Middle East J Dig Dis 2016;8:51-6. doi: 10.15171/mejdd.2016.07.

78. Fakheri H, Bari Z, Taghvaei T, Hosseini V, Maleki I, Valizadeh SM, et al. The Efficacy of Levofloxacin-based Triple Therapy for Helicobacter pylori Eradication after Failure with Clarithromycin-Containing Regimens. Govaresh 2018;22:in press.

79. Fakheri H, Bari Z, Taghvaei T, Hosseini V, Maleki I, Valizadeh SM, et al. The Efficacy of Levofloxacin-based Triple Therapy for Helicobacter pylori Eradication after Failure with Clarithromycin-Containing Regimens. Govaresh 2018;22:in press. 